\title{
The English Silk Industry in the Eighteenth Century.
}

$A S$ a competitor for supremacy in the silk industry England came A late into the field. For the actual production of the silkworm she was never qualified. The climate prevents mulberry leaves from being ready to receive the silkworms at the time they are hatched, ${ }^{1}$ and circular letters sent by James I in 1607 and 1608 to the lord lieutenants of English counties to encourage silk production in England represent an isolated and futile experiment. ${ }^{3}$ Having. however once embarked upon silk manufacture, the English people never long neglected it. There were silk weavers in the reign of Edward III, and a prohibition against imported silks, issued somewhat prematurely by Henry VI's government, was made perpotual with negligible effects by Henry VUI. A fellowship of throwsters, founded in 1562, was incorporated in 1629 , chiefly under the inspiring influence of Flemish refugees. In 1621 there were twelve foreign silk throwsters and hundreds of foreign weavers in the east end of London, ${ }^{3}$ while a cluster of silk workers in and about Cheapside in the days of James I attested the success of the new trade. ${ }^{4}$ In 1666 the number of persons engaged throughout England in the manufacture of silk was alleged by an optimist with no statistical skill to approach 40,000 . In 1685 the influx of the Huguenots from all parts of France placed the industry for the first time among great English enterprises. Figured silks, brocades, and paduasoys were woren by Lanson, Mariscot, and Monceaux, while Mongeorge disclosed to English eyes the secret of how to give lustre to silk taffety. ${ }^{5}$ In 1692 a Royal Lustring Company was incorporated. Its promoters pointed out that notwithstanding the growth of the manufacture here, 700,000l. of fully manufactured silk goods had still been annually imported from abroad between 1685 and 1693, and raised a cry for more effective protection. A committee of the house of commons accepted the company's statement that the number of looms employed in England

' Wardle's Silk (1887), p. xii.

$=$ Harleian Miscellany (1809), ii. 218.

- Smiles' Huguenots (1895), p. 103 ; Returns of Aliens dwelling in London, Publ. Huguenot Soc. x. (1900-1908).

- Rutland MFanuscripts, Hist. Mantuscripts Commission, Report xii. 5 (1889), i. 458.

- Woiss' French Protestant Refugees (tr. 1854), p. 253. 
declined from 768 in $1695-6$ to under 50 in 1697 owing to widespread smuggling by French and British privateers. ${ }^{\circ}$ In 1698 French manufactured silks were consequently prohibited, and in 1701 Indian and Chinese were similarly barred. During the war of the Spanish succession, the joint exigencies of revenue and the silk manufacture pushed duties on partially manufactured silks to a high point, but these were relased in 1719 . By that time the English silk trade had reached a volume twenty times greater than that of 1664 .

From this date the history of the industry in Great Britain falls into four periods. The years between 1713 and 1765 were marked by heavy duties falling short of prohibition. Between 1765 and 1826 fully manufactured silk imports were prohibited. and duties on other silks were proportionately high. The third period was introduced by a new tariff, devised by parliament in 1824, and coming into operation in July 1826. This tariff was reduced in 1828 and 1845 , until it became simply a 15 per cent. ad valorem duty on manufactured silk, and this was abolished in 1860. The fourth period, that of free trade, dating from Cobden's French treaty, may be here left unnoticed. It is proposed to examine in these pages the silk industry between 1713 and 1800 , partly as throwing light on the economic conditions of England during that strenuous age, and partly as reflecting the influence of politics and patriotism on the nation's economic theory and practice.

The sources from which English silk manufacturers then drew their raw material are the same to-day, but the proportions contributed by the different markets have been largely reversed. Turkey and the Levant were most important. Of the 4650 bales of $160 \mathrm{lbs}$. each which represented the British importation of raw silk in 1715,2500 came from these countries, as against 1300 from Italy and 850 from. India and the east. ${ }^{7}$ Turkish silk was used for damasks, silk stockings, and galloons. Organzine or double twisted silk had to be Italian. At Aleppo, 19s. or 20s. a pound was paid for Shervan and Georgia silk, of which price freight and duties counted nearly half. ${ }^{8}$ The Turkey Company's most valued import was sherbaffee, fine raw silk from Persia. ${ }^{\theta}$ Raw silk from Italy cost between 138 . and 268 . a pound (inclusive of duty) until Victor Amadeus II in 1724, and his successor in 1739, prohibited its exportation from Lombardy. ${ }^{10}$ Piedmontese thrown

- Report of the Hoube of Commons Committee to whom the Petition of the Boyal Lustring Company was referred (1698), passim.

' Haynes' Great Britain's Glory (1715), p. 13.

- Gee's Trade ard Navigation of Great Britain (1729), pp. 9, 98.

- Beapes' Lez Mercatoria (ed. 1813), ii. 60.

10 Edirburgh Reviero, xliii. (1826), 79. 
silk, which cost 20s. a pound on an average, was the best fine silk in the world, and continued to be imported, its only rival being that produced in Granada, Murcia and Valencia, where French merchants bought up the product. ${ }^{11}$ In 1756 unwrought silk from Naples was shipped to England.'2 Raw silk from India and China was deemed one of the East India Company's most useful imports. The duty on Bengal silk ras one-third more than that piaced on Italian, and on Chinese three times that on Bengal, a policy based on an error of judgment, and 'to the great damage of our nation,' ${ }^{13}$ as, owing to far more frequent silk 'crops' and to cheaper labour, Asiatic silk was naturally far less costly than European. Before 1770 the amount of annually imported raw silk from the East never exceeded $100,000 \mathrm{lbs}$., but in 1780 it rose to 200,000 , in 1800 to 500,000 , and in 1823 to $1,218,661$, more than six times the quantity then introduced from either Turkey or Italy. ${ }^{14}$ In the eighteenth century no one foresaw the rast development of China and Japan as markets for supplying raw silk, while the import of French raw silk, which became second in volume to that of oriental soon after 1800, was then denied to the English merchant.

Of Britain's rivals in the silk industry the French were easily first. Even after the import of their manufactures mas prohibited in 1765 their smuggled goods caused despair in Spitalfielde, and their efforts in neutral markets excited the complaint of the exporter. Their superiority is attested first by the large amount of silk that passed from Italy to France, and that returned to Italy in a manufactured state, ${ }^{15}$ and secondly by the English fondness for smuggled alamodes and lustrings. Dating its greatness from the time of Henry IV, Lyons stood pre-eminent for its silk manufacture throughout the century, but we have to note that it lost much by the enigration of the Huguenots, and that its rate of actual progress was slow. In $1739,18,093$ persons were employed in its silk trade; in 1777 there were 25,469 and in $1786,26,500 .^{16}$ The bulk of France's supply of raw silk came from the east, Italy, Sicily, and Spain to be manufactured principally at Lyons and Tours, though many other places-Beanvais, Toulouse, Montpellier, Algis, and the Rhone valley-were associated with the trade, and silk stockings were made at Dourdain and Nimes. In 1792 France possessed 29,000 silk looms, of which 18,000 were at Lyons, and she imported yearly during the period 1770-1800 some 89 millions of livres' worth of raw silk. ${ }^{17}$ Arthur Young's strictures on the French policy of amplifying that supply by fostering the growth of mulberry trees on the plains of Languedoc and Dauphiné

\footnotetext{
11 Gee, p. 94.

1. Gee, p. 27.

13 Nugent's Grand Toutr (1756). iii. 401.

"Gee, p. 14.

'H Edirburgh Reviezo, xliii. (1826), 79.

"Young's Travels in France (1792), ii. 37.
} 
and on other sites less naturally qualified, ${ }^{18}$ did not rouse a responsive echo in that mercantilist age.

The competition of Italy and Sicily was less lieen, as their silk exports were confined to special styles. England herself bought manufactured silks from Messina, Palermo, Florence, Pisa, und Naples, brocades from Genoa, and stockings from Milan ; ${ }^{19}$ and she readily admitted the supremacy of the Piedmontese mechanics, whose ingenuity she hoped to copy. A manufacture of silk rose in Valencis after $1750 .{ }^{20}$ Otherwise there were no other European competitors for the English shipper to face. What he resented most after the rivalry of France was the unlawful cargoes of wholly or partially manufactured goods from China or India, with which the East India Company stealthily enhanced the ralue of their shipments. Though ignorance of chemicul science and of mechanical reeling limited the capacity of Asiatic weavers, their manufacture of silk reached back to remote ages, and their natural colours and secret embroidery processes made their goods as acceptable as European, even if defective in regularity. ${ }^{21}$ 'Prodigious quantities' of this stuff, made principally in Nanking and Chekiang, from the silkworms of Shantung and Tongking, were smuggled into Great Britain either by the East India Company or by way of Ireland, the Isle of Man or the plantations. ${ }^{29}$

Eighteenth century England faced this commercial opposition with a system of whole-hearted protection. The sill manufacturers pointed throughout the century at the wonderful effect that Marlborough's war had had upon the importation of French sillis and the encouragement of English industry. Their written appeals for state interference still ring with sincerity and strength. That the country should make its own silk instead of pandering to the foreigner is Joshua Gee's principle, and is expounded with much clearness and felicity in his tract of 1729 , called The Trade and Nacigation of Great Britain considered, and designed 'to prevent the importation of such foreign commodities as may be raised at home.' The same principle is applauded in De Foe's Plan of the English Commerce. In 'T'rade Rerived, a witty 'dialogue' of 1789, the Englishwoman is reviled for diverting her expenditure from Britishmade goods to French-made luxuries. Half a million sterling is yearly

Carried from hence foreigners' work to buy ;

What numbers of our poor would that employ!

How many helpless, hopeless families free

From the sad state of want and misery. ${ }^{23}$

1" Young's Travels in France (1792), ii. 19, 38.

1" Beawes' Lex Mercatoria, ii. 5-7.

$=\sim$ Ibid. ii. p. 135 .

II Wardle's Silk, pp. 11, 16, 44.

= Gee's Trade and Natigation, p. 28; Hagnes' Great Britain's Glory, p. 85 Calcndar of Tieusury Looks and Papers, 1731-4, p. 409.

$\rightarrow$ Trade Reviced (1739), p. 12. 
Oct.

To a generation of home workers, ignorant of free trade economics and keenly alive to the then accepted doctrine of the balance of trade, the silk weaver's complaint against parliament made a strong appeal.

'Tis indeed sarprising those should let our trade

$\mathrm{Be}, \mathrm{ss}$ it is, to foreign lands conveyed;

The poor are in our streets complaining too;

They fain would work, but have no work to do. ${ }^{24}$

From 1713 to 1765 sach propaganda never waned. The movement reflected the political ideals of western Europe in that age. The French government published no less than seventy-nine edicts against the use of foreign silk stuffs between October 1686 and March 1757, and prohibited the sale of Indian and Levantine fabrics, whether genuine or spuriously made at Lyons. ${ }^{25}$ The example set by Queen Mary in wearing English-made hoods and scarves was a fitting prelude to continuous agitation for the prohibition of foreign-made silks. In January 1717/8 all the silk-manufacturing districts in EnglandLondon, Dorset, Lancashire, Cheshire, Staffordshire-representing many thousands of throwsters, spinners, twisters, winders and dyers, besought the house of commons for help, and deplored the abandonment of silk for serge or stuff by tailors in making buttons and button holes. Minute accounts of the exports and imports from and to the East Indies were ordered to be taken on the following 6 February, ${ }^{25}$ while on 20 February $1717 / 8$ the bailiffs, wardens and assistants of the London silk-weavers' ' trade, art, and mystery' petitioned parliament to prevent more effectually the clandestine importation of foreign wrought silk. ${ }^{27}$ In 1719 a depression in the trade aroused the cry that the whole tariff question was not so much one for capitalists and employers, but was whether or no poor journeymen should be saved from starvation. ${ }^{23}$ In 1793 the Silk Throwers' Company attacked the treasury for its neglect in enforcing the laws 2 William and Mary c. 9, and 1 Anne c. 27, which forbade the importation of foreign thrown ailk from Italy and Sicily. ${ }^{29}$ In 1736 men complained that the French after satisfying their own home market were 'dumping' silk in England at ruinous prices. ${ }^{30}$ After Pitt's triumphs in the Seven Years' War the complete success of the protectionist school became but a question of time. The duties levied on wrought silks were first raised to defray the charges of the war establishment in America. ${ }^{31}$ On 9 April 1764 a procession of silk weavers marched from Spitalfields to St. James's,

11 Trads Revived, p. 16.

"Goderd, L'Outrier on Soie, pp. 356-7.

20 Joumals of the House of Commons, xviii. 693.

IT Ibid. Iviii. $746 . \quad$ "Brief State of the Question (1719), p. 43.

- Calendar of Treasury Books and Papers, 1731-4, p. 420.

- Lloyd's Thoughts on Trade (17B6), p. 6.

"Annual Register, 1764, p. 63. 
where two manufacturers explained their grievances to the queen. ${ }^{32}$ Next year another gathering met 'by beat of drum' in Spitalfields and Moorfields, and, 'pallid and emaciated,' paraded through the City and West End. They broke the windows of French firms and of nobles suspected of buying French silk. But ' a sessonable subscription' brought momentary relief, and a prohibitive tariff in the same year effected lasting satisfaction..$^{33}$

No less fierce was the jeslousy that excluded Asiatic goods in a manufactured state. Pointing with admiration at French edicta of July 1700 and December 1701 , which respectively limited the amount of silk to be imported by the French East India Company, and prohibited its importation of any gold or silver lace, ${ }^{34}$ the English silk interest always deplored that the government tolerated in practice what it by law forbade. 'England's Adrocate, England's Monitor,' a tract of 1699 , had been largely responsible for the statutory prohibition of such imports in 1701, and its lessons were never forgotten. In this painful 'Intreaty for Help in behalf of the English Silk Weavers and Silk Throwsters,' men could read of the unemployment of four-fifths of those employed in such industries under the pressure of the unfair competition of goods made in the east, where labour was extremely cheap. Starvation was meanwhile the lot of all London from Aldgate to Shoreditch, and from Stepney to Southwark. 'Alas! we may now say with the brazen head, Time was.' ${ }^{25}$ Even after the entry into England of all silk goods from Asia, other than crapes and tiffanies, was forbidden, Indian calicoes were the bane of the English silk manufacturer, for women began to abandon silk dresses for this cheaper garb and to attire themselves 'more like the merry andrews of Bartholomew Fair than like the ladies and wives of a trading people.' ${ }^{86}$ Consignments of Chinese silks to the East India Company were sometimes found to cover forbidden parcels of thrown. ${ }^{37}$

Hanoverian England supported the main scheme of protection by several devices to amplify the sources of raw material, to develop industrial ingenuity and invention, and to stimulate the export of the manufactured article. The first object was attempted in relation to the silk trade by a determined effort to produce silk in the American plantations upon the same principle that we now encourage cotton growing in British West Africa. Bacon's essay on Plantations laid down that 'Growing silke, if any be, is a likely commoditie,' and the task was endeared to the English people by their ideal of a self-sufficing empire. Little was done in this

3 Annual Registor, 1764, p. 64.

s Ibid. 1765 , pp. $41-42$.

4 Godard, L'Uuvrier en Soie, p. 209. 2s England'a Advocate (1699), p. 6.

2* Brief State of the Question (1719), p. 11.

I Calendar of Treasury Books and Papers, 1739-41, p. 518. 
respect before the reign of George II. In 1609 James I ordered the Virginia Company to grow mulberry trees; in 1622 that company published a tract on silkworms, and in 1655 a treatise on their cultivation was published by Hartlib. In 1668 Charles II received a small sample of American raised silk. It was not however until the foundation of Georgia was contemplated that the hopes of producing silk on British soil rose high. The Reasons for establishing the Colony of Georgia, written in 1733, stated that England was then paying $300,000 l$. a year for 300,000 lbs. weight of thrown silk. ${ }^{38}$ Raw silk from Italy was unobtainable. Consequently Georgia silk would both relieve England of her money drain and give work to silk throwers as well as silk manufacturers. The same tract quoted Sir Thomas Lombe's appreciation of silk raised from silkworms in Carolina, ${ }^{39}$ and a year later that expert gave his approval to $8 \mathrm{lbs}$. of cocoons brought, it was said, by Oglethorpe from Georgia itself, and destined to form the fabric of one of Queen Caroline's most handsome gowns. Ten mulberry trees had to be grown on every acre of land granted to settlers; two Piedmontese called Amatis and Camuze were sent out with an armoury of copper basins and reeling machines. They reported with cheerful alacrity that the soil was as good as that of Italy, and that they could produce ' $\mathrm{a}$ fine, clean, and even thread.' Mulberry trees were planted every year between 1732 and 1742, and the trustees were advised to offer liberal bounties. ${ }^{40}$ In 1736 the author of The National Merchant predicted that Britons would produce wine and silk 'in time' in the new colony, ${ }^{41}$ and De Foe pointed out that Italy and France had also been at one stage no less destitute of the raw material. ${ }^{43}$ The shipment of some silk samples in 1739 aroused fresh enthusiasm. But after 1742 the hope of Georgia silk sank, and its cultivation was finally abandoned in 1790 .

British enterprise however did not confine its sills experiments to one province. The neighbouring province of South Carolina had for generations past been thought a possible source of sapply. In 1671 the lords proprietors sought for mulberry trees from Virginia, ${ }^{43}$ and in 1677 they directed the governor and council at Ashley River to engage a skilled cultivator. ${ }^{41}$ In 1679 eighty French protestants in London, led by Jacob Guérard, a Norman, and René Petit of Rouen, finding themselves in danger of being driven by their poverty to 'return into Babylon,' asked for a

\footnotetext{
${ }^{25}$ Reasons for establishing Georgia (1733), pp. 6, 8.

to State of the Province of Georgia (1742), p. 19.

"The National Merchant (1786), p. 113.

"De Foe's Plan of the English Comnerce (1737), p. 86.

t3 Calendar of State Papers, Col. Series, America and W. Indies, 1669-74, p. 211.

4 Ibid. 1677-80, p. 59.

Ibid. p. 7.
} 
haven of refuge in Carolina,45 were lent $2000 l$. by the government, and were allowed to establish silk weaving settlements at New Bordeaux and on the banks of the River Santee. ${ }^{46}$ A plantation called Silkhope was founded in 1699.17 The same ambition prompted the efforts of a later generation of colonists in South Carolina, who petitioned the treasury in May 1742 to exempt plantation silk from import daties, ${ }^{48}$ and who shipped $118 \mathrm{lbs}$. of raw silk to England in 1750. Early in 1765 the governor offered a reward of 500 dollars to the first of certain immigrants from Nova Scotia to the western part of the province who should produce there $10 \mathrm{lbs}$. weight of raw silk, ${ }^{49}$ but in December of that year Lord Dartmouth was informed that the silk industry in South Carolina was on the decline. ${ }^{60}$ In spite of help from England and much advice, it never revived.

No less devoted were the attempts of other settlers with the same object. The Virginians are alleged to have sent silk to make a coronation dress for Charles I. ${ }^{11}$ Guided by the happy English intuition, which associates the ideal of empire with the practice of liberty, they welcomed Walloons and Huguenots as early as 1621, and at a later date they engaged French and Armenian experts : one of the latter received 4000 lbs. of tobacco for raising 10 lbs. of silk. $300 \mathrm{lbs}$. of raw silk was sent by Berkeley and the council and burgesses of Virginia to Charles II in July 1668, ' being the first fruites of their labour in that kind,' which gift the king was pleased to command 'to be wrought up for the use of our own person.' s2 In 1730 the same quantity of silk was again shipped to England. Specimens of silk were despatched from Pennsylvania in 1726, and in $17712300 \mathrm{lbs}$. were produced at Philadelphia, from which a gown was made for Queen Charlotte. In 1747 Governor Law of Connecticut wore a home-made silk coat and home-made silk stockings. In 1763 concessions of land in Florida up to 20,000 acres were offered to intending cultivators of silk. ${ }^{53}$ Samuel Pullein, an Irish clergyman, spent immense labour in advocating colonial silk enterprise. In 1750 he translated Vida's Silkworm into English verse, and in 1758 he published The Culture of Silk for the Use of the American Colonies. He argued that the mulberry could grow anywhere in America and, unlike tobacco, would enrich more than merely the planter class. ${ }^{3+} \mathrm{He}$

4 Calendar of Stato Papers, Col. Series, America and W. Indies, 1677-80 pp. $\mathbf{3 8 8 , 4 2 8 .}$

46 Weiss' French Protestant Refugees, p. 309.

17 Century Magasine, v. (1884), 488.

4- Calendar of Treasury Books and Papors, 1742-5, p. 163.

- Annual Register, 1765, p. 75.

- Hist. Mfanuscripts Commission, Report xiv. 10. Dartmouth MSS. (1895), ii. 28.

s1 Contury Magasine, v. (1884), 482.

s2 Cal. S. P. Col. America and W. Indies, 1661-8, pp. 594, 627.

s Annual Register, 1768, p. 111.

"Pallein's Culture of Silk (1758), p. 8. 
explained elaborately how to choose rich, loose monld as most suitable soil, how to plant long lines of mulberry trees from north to south, and how best to reel the silk into balls. The prince of Wales' patronage was given expressly to this ardent tract, for, as Pullein declared, 'Britain's commerce has its glory in the care of her princes.' Benjamin Franklin's enthusiasm for the same imperial project was keen and deliberate. Being of opinion that silk was 'the happiest of all inventions for clothing,' he sent for a French treatise on the management of silkworms in 1769 , and urged that as mulberry trees required less land than did pasturage, and did not impoverish the soil like flax and hemp, they ought to be plented in ebundance. Grass would grow beneath mulberry avenues. Raw silk could be sold at from 208. to 258 . a pound, and manufactured silk wore well. In 1771 he bought samples of reelers from Italy and of eggs from Valencia. ${ }^{\text {bo }}$ The home government watched such endeavours with exemplary interest, bearing in mind how great a rise in the value of land in Italy had been due to its aptitude for growing mulberries. By the statute 9 Geo. III, c. 38, a bounty on the importation of raw silk from British plantations was offered for twenty-one years as from 1 January 1770 ; for the first seven years $25 l$. would be paid for every consignment of the value of $100 l$; for the second seven years, $20 l$., and for the third, $15 l$.

The explanation of the failure of the old colonial system to elicit any substantial return for its efforts to make the empire produce its own silk lies in the dearness of labour in America. ${ }^{57}$ Slaves were at one time expected to be useful in this respect, ${ }^{68}$ but the management of silkworma and the preparation of silk proved to require far more skill and concentration of mind than had been anticipated. Both the actual and the nominal rates of wages for adult white labour were infinitely higher in the colonies than in Italy or France, and consequently the higher cost of production wes from the first fatal to the industry in North Americe. ${ }^{89}$ Apart from this disqualification, there was nothing unreasoneble in the enterprise, for the southern provinces were in the same latitude as Canton and Turkey, were by nature as fertile as Bengal, ${ }^{, 0}$ and were far better adapted to the purpose than Sweden, which was then making no less valiant experiments in the same cause. ${ }^{61}$

The same principle of political economy that barred the foreign merchant from the home market, and sought to develop the supply of raw silk in the plantations, led to other state actions in England.

4 Bigelow's Franklin (1890), ii. 42.

- Mid. ii. $80 . \quad$ "Gentleman's Magazine xxvi. (1756), 161.

- Gee's Trado and Navigation, p. 21 ; Gentleman's Magasine xxvi. (1756), 162.

- Adam Smith's Wealth of Nations (1776), book iv. ch. 8.

- Gent. Mag. xxvi. (1756), $168 . \quad$ "Sandbärg's Sweden (1904), p. 807. 
In order to encourage the export trade, a bounty upon all wrought silk shipped from Great Britain was recommended by the council for trade and the plantations in 1719,62 and adopted to the extent of 38. a pound by the statute $8 \mathrm{Geo}$. I, c. 15. In 1731 merchents at Glasgow, Greenock, and Leith claimed to participate in the bounty as being exporters of coverlets and rugs, in which 'the coarsest refuse or hasks of silk' ${ }^{63}$ were ingredients.

Of far more importance was the help given by the government to English inventors and patentees. Details of the mechanism, which had long made Italian engines for winding, spinning, and twisting raw silk into organzine the envy of the world and the source of an absolute monopoly of that material, had been published in England in 1607 and 1621, but had never been adopted in practice. In 1717 Thomas and John Lombe rented for $8 l$. an island on the Derwent near Derby, and built a mill on oaken piles at the cost of $30,000 l$. On 8 September 1718 Thomas patented three engines contrived on the Italian model, and these were built and worked by his brother John and two Italian artificers, whom they had enticed from Turin. John Lombe was murdered in 1722, but Thomas brought the works to a high perfection, notwithstanding the difficalty caused by the king of Sardinia's prohibition of the export of the necessary raw silk from Piedmont on pain of death. On 28 January 1731/2 Sir Thomas Lombe petitioned the house of commons for the prolongation of his expiring patent on the ground that the policy of the Sardinian government had prevented the full exercise of his rights. ${ }^{64}$ A committee of the house reported on 11 February that Lombe's mill had reduced the price of the fine Italian organzine required for weaving lustrings and alamodes by 58. per pound (i.e. by 20 per cent.) and had even forced Italian makers to lower their charge from 278 . to $218.6 d$. $^{\text {G. }}$ Prolongation of the patent rights was therefore recommended, but on 9 March manufacturers at Manchester, Macclesfield, Leek, and Stockport petitioned to the contrary, while the Derby corporation objected to the proposal on 26 February as tending to keep the poor at home and thereby to increase the local rates. ${ }^{\text {is }}$ Derby wool manufacturers resented the competition of silk; London throwers that of machinery; Blackburn manufacturers that of state-eided rivals. ${ }^{87}$ Accordingly parliement voted Lombe a reward of $14,000 l$. in full satisfaction of his claims to national recompense, ${ }^{88}$ and this sum was paid by the treasury on 27 July $1732 .{ }^{.9}$ Models

- Calondar of Treasury Papers, 1714-9, p. 487.

- Calondar of Treasury Books and Papers, 1781-1, pp. 41, 57. There were no true silk manufacturers in Scotland before 1822.

" Journals of the House of Commons, xxi. 782.

- Ibid.795. $\quad$ Ibid.840. $\quad$ Ibid. $842 . \quad$ Tbid. 855.

- Calendar of Treasury Books and Papers, 1781-1, p. 389. 
of his threc engines were made in February 1739 by Robert Smith, the king's ' master of mechanics,' so that knowledge of how to vie with Italy might be more diffused. ${ }^{70}$ In the same spirit letters patent were granted for fourteen years to John Apletre in 1718 for raising raw silk by experiments in Chelsea Park. ${ }^{71}$ The inventor had designed an evaporating stove to keep eggs warm, and an engine called 'the eggs' chest,' and he planted a number of mulberry trees in the park. Little however was heard of this scheme when once a company had been formed with a capital of a million sterling, of which $1250 l$. was paid up on allotment. ${ }^{72}$

It is of much interest to consider to what extent the English people were repaid for so much work and fervour. It must be admitted that they never wholly wrested supremacy in the silk trade from the French. The latter had several great advantages. In the first place, labour was far cheaper, and in this case cheap labour was not counterbalanced by any English superiority in taste or workmanship. Secondly, the supply of raw silk in France was nearer at hand and more abundant. As we have seen, a considerable 'crop' was raised in France itself. Moreover, though the English tariff was scientific to the extent of placing a far heavier duty on dyed than on undyed thrown silk or organzine, and on the latter than on 'tram ' and singles, it maintained a duty on raw silk to the detriment of the manufacturer. This duty was 48. a pound on silk from Bengal, and 5s. $7 \frac{1}{2} d$. on silk from elsewhere, the corresponding French duty being only $4 \frac{1}{d} d .^{73}$ Judged even by its own economic standard, the state seems to have been here entangled in a singular fallacy. Thirdly, the vagaries of English fashion were utterly uninfluenced by any patriotic preferences. Instead of supporting home industries, the consumer constantly sought for French goods, notwithstanding all preventive laws and all the proper promptings of national feeling. Women asked for Pompadour caps, Orleans handkerchiefs, and Conti mantlets at the bidding of cosmopolitan dressmakers, who, instead of considering pure taste and British interests, insisted on recommending French gowns and styles, and sent ' the lady who is gracefully formed like the peahen, walking in the public gardens with the bobtail of the duck.' ${ }^{74}$ Smuggled sillk was especially prized, and makers at Manchester and Spitalfields tried to pass off their goods as being smuggled over from France. ${ }^{75}$ Moreover, without reference to foreign competition, the manufacture of a luxury is inevitably liable to recurring depres-

7 Calendar of Treasury Books and Papers, 1739-41, p. 12. For the Italian silk industry see Prato, La Vita Economica in Piemonte (1908), pp. 218-35, 313.

"Produce of India, Italy, and France raised in England (1720), p. 7.

7 Ibid. p. $18 . \quad$ Edirburgh Review, xliii. (1826), 82-8.

" Shebbeare's Letters on the English Nation (1755), ii. 229.

"Edinburgh Review. rliii. (1826), 81. 
sion. A sudden reaction against the ase of silk for both dress and furniture arose in 1785, and within eight years four thousand looms were shut in Spitalfields. ${ }^{i 6}$

Nevertheless, in spite of disappointments, the silk industry made immense headway in England under the protectionist gystem. The home market was all but monopolised; even in 1830, after the introduction of a 30 per cent. ad valorem duty, imported French thrown silk only amounted to $213,991 \mathrm{lbs}$. The demand for raw eilk from abroad grew steadily, and upon it depended the standard market prices charged at Turin." Between 1765 and 1767 some 715,000 lbs. were on an average thrown annually in England, an average which rose to 881,000 between 1785 and 1807 , and to $1,110,000$ between 1801 and 1812. For every $2200 \mathrm{lbs}$. of raw silk manufactured in England 5000l. were spent in wages. English merchants shipped English-made silk to America, Germany, Russia, Italy, Portugal, Holland, Ireland, and Spain. ${ }^{78}$ In 1700 Spitalfields was the only centre of a considerable silk trade, and thither the distressed French weaving colony of Canterbury had migrated in $1694 .^{79}$ By the year 1800 the industry had been entirely transformed, and ranked among England's greatest undertakings. The first silk mill at Macclesfield was only built in 1756, but before 1800 it was widely noted for its buttons and ribbons, and had a population of 8700 people. ${ }^{80}$ Congleton had only 3861 inhabitants in 1801, but three-fifths of that number worked in silk mills, and its spun silk was in great demand. ${ }^{81}$ James Brindley built the water wheel for its first silk mill in $\mathbf{1 7 5 2}$. Coventry ribbons became worldfamous. Manchester possessed 10,000 silk weavers in 1815; Stockport, Middleton, Leek, Derby, Glossop, Chesterfield, Bishop Stortford, Sherborne, Stalbridge, and Barnstaple each acquired proficiency in various departments of the silk trade; Essex boasted of three silk mills, and of an army of home workers in the villages adjacent to the East End of London. ${ }^{82}$ Dublin, thanks to Huguenot immigrants from the west of France, prospered in the same employment until

74 Edinburgh Review, xliii. (1826), p. 79.

"Young's Travels in France, ii. 220.

78 Beawes' Lex Mercatoria, ii. 43, 49, 56, 112; Shillington \& Chapman's England and Portugal (1907), p. 264 ; Boyer's Political State of Great Britain, xl. (1730) 860 .

19 The Irterest of England considered (1720), p. 25

w Finney's Macklesfelde (1873), p. 10; Beawes' Lex Mercatoria, ii. 6; Corry's Macclesfield (1817), passim.

"Head's Congleton (1887), pp. 147-8; Beawes, ii. 6; Corrg's Congleton (1817), p. 196.

8: Vict. County History, Lancashirs (1908), ii. 311, 394 ; Dorbyshire (1907), ji. 872 : Essex (1907), ii. 462 ; Dorset (1908), ii. 362; Hist. Manuscripts Commission, Report xii. 9, Ketton Mfantuscripts (1899), p. 219; Clarke's Tour through the South of England (1793), p. 126 ; De Foe's Eruglish Tradesman (1726), p. 401 ; Hutton's Derby (1791), p. 204.

vOL. XXIV. - NO. XCVI. 
the Union. ${ }^{83}$ Even in France the skill of the English workers occasionally won a precarious foothold on the public taste. ${ }^{\text {st }}$ During the prevalence of Anglomania, the French court bought English silk, and thereby provoked the indignation of those who supported the national silk industry. ${ }^{85}$

It is impossible to deng that the favour shown by the British government towards this particular trade during the eighteenth century fostered a large industry, and generated an important means of employment. The workers of the time were fully alive to the utility of having the largest possible number of trades flourishing in the country and thus minimising the chances of general depression. The younger Pitt realised their apprehensions in this respect, when he shrank from extending the French commercial treaty of 26 September 1786, to any silk goods other than gauze, which the two contracting states agreed to admit with a 12 per cent. ad valurem duty. 'I tremble at the very mention of a repeal of our manufactured silk laws,' wrote Rose to Eden in May 1786, owing to the dangerous attitude of the Spitalfields operatives towards any suggestion of whittling down our prohibitive system. ${ }^{88}$ Pitt confessed that beyond permitting reciprocity for ganze, which gave England a striking advantage, he dared not invite French competition in the home market. ${ }^{87}$ Nor was the suspicion of the workers that free trade meant their ruin ill-founded. Since the removal of the 15 per cent. duty in 1860, the pressure of growing foreign competition has been overwhelming. ${ }^{88}$ The census of 1901 disclosed that only 39,095 persons were occupied in working silk, as against 130,723 such persons in the census of 1851 . The number of wesvers in Spitalfields has fallen from 40,000 to 300 , in Derby from 6000 to 660 , in Coventry from over 15,000 to under 700. Seven-eighths of the silk mills at Congleton and two-thirds of those at Macclesfield have ceased to exist. Silk exports have shrunk almost to extinction, while imported silk goods have grown steadily in volume. Wages have fallen. Working for longer hours and requiring far less remuneration to maintain their lower standard of comfort, the silk workers of Lyons and Milan have ousted their English rivals in most neutral markets and have competed hotly with them in Great Britain itself.

Upon these facts the orthodox economist might argue that Hanoverian England was at fault in bolstering up an industry

"Wardle's Silk, p. 139; Lloyd's Thoughts on Trade (1736), p. 10; Publications of the Huguenot Saciety, vols, vii., xiv.

4 Shebbeare's Lettors on the English Nation, ii. 200.

is Godard, L'Ouvrier on Soie, pp. 212-3.

* Auckland Journal and Correspondence (ed. 1861), i. 120.

"Ibid. i. 161.

soports of the Tariff Commission, vol. ii. part 6; Head's Congleton, passim; Vict. Counfy Hist., Derby (1907), ii. 372. 
incapable of thriving on its own merits. Such a view hardly dawned upon the country before Adam Smith's time. Arthur Young, writing in 1792, considered bounties offered to silk producere by the Society of Arts 'a great but harmless folly,' ${ }^{80}$ but in the main the political theory of the age was wholly at variance with the modern conception that the consumer's interest is the first consideration. Silk importers and brokers of East Indian goods appear to have been the only active opponents of the general policy. The ordinary Briton did not mind paying far in excess of the natural cost of silk; had he appreciated free trade, he might in fact have bought fully manufactured Asiatic silk for the same price as that charged for the raw material to the English manufacturer. ${ }^{90}$ The prevalence of a vast system of smuggling was a further feature of the time, from which the economic sehool of a later date drew not unjustly a hostile moral. In the years 1724 to 1781 inclusive, only 399 lbs. weight of wrought silk was actually entered in the British customs, although it was notorious that nearly half the silk then worn in England had been made in France. ${ }^{01}$ As late as 1827 only 5 per cent. of the silk goods that were registered at French ports as destined for Englend were notified at British custom houses. A mere glance at the Treasury Papers of the time shows how general was the running of these goods, ${ }^{02}$ and in 1799 we find even the Manchester Commercial Society protesting against its prevalence. ${ }^{93}$

Such defects in their system were however of minor consequence to the generations which fought with France for colonial and maritime supremacy under the inspiration of Pitt's imperial ideals. A self-sufficing empire was its dream; British work for British workers was its accepted creed. Rightly or wrongly, it identified the prevailing methods of government policy with the interests of the poor. The argument of free importers that labour ought to flow into channels more naturally productive was, accord. ing to one writer, similar to the selfish wish of the sexton of Cripplegate during the great plague, who wanted mortality to continue unabated that he might have the burial foes." Silk weavers could not become bricklayers at a moment's notice.95 In 1719 a pamphlet, written to persuade the nation to revert to a scheme of higher duties, said that every yard of manufactured silk imported deprived the labourer of support. One loom alone meant employment for four hands. It may indeed be fairly admitted that

- Young's Travels in France, ii. 88.

- Edinburgh Reviow, xliii. (1826), p. 79.

"Reasons for establishing Georgia (1783), p. 9.

- Calondar of Treasury Papers, 1714-9, pp. 187, 151, 209.

n Helm's Manchester Chamber of Commerce (1895), p. 57.

"Brief State of the Gustion (1719), p. 47.

"The Waaver's True Case (1719), p. 35. 
although unemployment only occasionally troubled the serenity of English life in the eighteenth century, there were still good reasons for appreciating the growth of the silk industry in this respect. One hundredweight of Legee Turkish silk would provide employment for 297 persons weekly, comprising throwers, winders, warpers, dyers, quillers and-weavers, and for this raw material, fully manufactured English cloth was given in exchange ${ }^{26}$ The author of Great Britain's Glory, a tract of 1715 , gives no less eloquent statistics as to the number of hands employed in making ribbons from Italian silk, and stockings and handkerchiefs from Bellendine. ${ }^{97}$ Nor was this merely a secondary objective to the statesmen who contemplated the silk manufactare taking a place among great English staples. ${ }^{98}$ The expressed reason for stemming the invasion of the home market by oriental silks was the consequent desolation of Spitalfields, and the act that restricted the silk sales of the East India Company was itself intituled an act 'for the more effectual employing the poor.' Those who pressed parlisment in 1729 to adopt with regard to silk the principle embodied in the merchandise marks act of our own time, claimed to champion the cause 'of the poor, the old and infirm people, and the small and helpless babes.' ${ }^{9 \theta}$ Sir T.F. Buxton described the introduction of foreignmade silks in 1816 as 'contrary to the laws of the land, contrary to higher laws, justice, charity.' ${ }^{100}$ A drawback allowed by the statute 8 George I, c. 15, on the re-exportation of silk stuffs which had been imported from abroad in a partially manufactured state, was designed to safeguard the English shipping interest.

The condition of the silk workers during the eighteenth century is not directly relevant to the economic theory of the time, as any general regulation of labour was then beyond the bounds of political speculation. It was also very variable. Silk factories were not numerous even during the last half of the century. Work was largely entrusted by manufacturers to undertakers who distributed it among women, boys, and girls in country districts. In some cases, it was given at first hand to journeymen who owned their own looms. Naturally conditions were not the same in Spitalfields and the villages of Cheshire. It was thought at the time that female and child labour ranked high among the blessings conferred upon the nation by the silk industry. Three-quarters of the single hand weavers in Staffordshire and Warwickshire were women, and then, as now, men took but small part in the industry at Macclesfield. Ten boys were ordinarily employed in weaving two lbs. of silk into silver thread, and at Spital-

* Great Britain's Glory (1715), p. 11.

" Tbid. p. 12.

- Interest of England considered (1720), p. 3.

- Observations on the Bill for Better Employing tho Poor, \&o. (1729), p. 1.

in Speech on Distress in Spitalfields (1816), p. 7. 
fields ${ }^{101}$ they were employed in large numbers ' to the great relief, ease, and comfort of their poor parents.' ${ }^{102}$ Women, boys, and girls were the most violent assailants of the ladies who by werring calico gowns in 1719 appeared to sound the knell of the silk trade's prosperity. ${ }^{103}$ One of the worst effects of the decline of the fine cloth trade in Wiltshire was said to be the resultant unemployment of children, which made them 'a dead weight upon their parents' hands.' ${ }^{0 t}$ Consequently the easily learnt practices of winding and reeling silk into hanks were very dear to thrifty English parents. ${ }^{105} \mathrm{High}$ pattens were lashed to the feet of the boys employed in Lombe's mill at Derby when they were too small to reach the machinery. 'To this curious but wretched place,' writes Hutton, the local historian, 'I was bound apprentice for seven years, which I always consider the most unhappy of my life.' 100 We must not deem it a vice peculiar to the silk industry that Macclesfield children used to be hired out at the age of six for the wage of $6 d$. a week during the first year, $9 d$. during the second, and $18.3 d$. during the next three years. ${ }^{107}$ The generation which won victory at Plassey and Quebec, at Quiberon Bay and Bunker Hill, was not humane.

The rate of wages was generally low. A weaver is said to have earned abuut $58.7 d$. a week in $1715,{ }^{108}$ and in $179548.6 d$. for single hand work, and from 88 . to 128 . if working at a loom. During and after the industrial revolution his wages rose rapidly wherever other manufactures like cotton spinning enhanced the demand for labour. In 1770 silk gingham makers at Manchester earned 78. 6 d. a week, ${ }^{109}$ while in 1776 a Macclesfield millman was paid 78., and a woman doubler 3s. 6d. Fifteen years later the competition of the cotton mills had driven the Macclesfield millman's wages up to 16s., the doubler's to 10 s., and even the child's pittance to sums ranging from $28.6 d$. to 58 . During the French war some silk weavers at Macclesfield earned nearly $9 l$. a week, and the town's prosperity was amazing. ${ }^{10}$ After 1815 wages declined. Dorset millhands were given only 48. $6 \mathrm{~d}$. in $1881^{111}$, while in 1817 broad ribbon weavers were paid wages 'not sufficient for the maintenance of even a small family.' ${ }^{112}$ Conditions ruling in Spitalfields were distinctive.

101 Great Britain's Glory, p. 13.

102 England's tdrocate (1699), p. 5 ; Brag's Tour (17R3), p. 107.

102 The Weaver's True Case, p. 41.

10t The Misery of the Miserable (1739), p. 13.

1es Clarke's Tour through the South of Englankl, p. 126.

10* Hutton's Derby (1791), pp. 192-3.

102 Finney's Macklesfelde, p. 122 ; Corry's Macclesficld, p. 166.

108 Great Britain's Glory, p. 11.

100 Young's Tour through the North of Eiugland (1770), iii. 246.

110 Corry's Macclesfield, pp. 166-192.

'1' Victoria County History, Dorset, ii. 363.

II Minutes of Evidence, Report of Committee on Poor Lavos (1817), p. 214. 
The period 1768-72 was one of industrial war between employers and employed, and closed in special legislation, to which later industrial history has given some celebrity. The riots of 1763 and 1769 were particularly grave. In the former year 2000 workmen, 'masked and disguised as sailors,' broke the looms and were only prevented from slaying the master silk weavers by the interference of regular troops. ${ }^{113}$ In January 1768 a similar outbreak was threatened,14 and between September and December 1769 soldiers were required to maintain peace. ${ }^{115}$ Rioters convicted of cutting looms were hanged in December 1769 and January 1770. ${ }^{116}$ On 16 April 1771 one Daniel Clarke, who had given evidence against the offenders, was half drowned and then stoned to death by the mob. ${ }^{117}$ In those terrible days a subscription of $2 d$. per loom was paid by all weavers still at work towards the support of the unemployed, and thus were sown the seeds of the later Trade Unionism. The government of the day met the emergeney by legislation in a panic. By a statute 13 George III, c. 68, the wages of Spitalfields journeymen were to be assessed as from 1 July 1773 by the lord mayor and justices, and employers evading their regulations were to be fined for the benefit of needy weavers and their families. Sweating nevertheless was rife in 1785 . In 1792 the statute 32 George III, c. 44, extended the scope of the law to those employed in menufactures where silk was mixed with other materials, and in 1811 females were included by the statute 51 George III, c. 7. The Spitalfields Acts were enforced by means of elaborate price lists, and a journeymen's society was formed to prosecute employers in default. Although there were local movemonts in Coventry, Nuneaton, and Macclesfield in 1818 to make the operation of the acts universal, they-were abolished in 1824, and their general resalt seems to have been unfortunate. Labour at Spitalfields grew more oppressed than ever by poverty, ${ }^{118}$ and the levelling effects of its minimum wage sent away the best workmen to thrive in the freer air of Cheshire, Manchester, Taunton, and Norwich. ${ }^{119}$

In view of the prevailing cheapness of meat, bread, butter, cheese, and beer before the industrial revolution, ${ }^{130}$ and of the fact that many silk weavers were able to combine their handicraft with agricultural pursuits, the lowness of wages must not lead us to take too gloomy a view of the welfare of the workers. Indeed the wages themselves are little below the normal standards of other English manufactures at that period, and are practically on a level with

\footnotetext{
11. Home Office Papers, 1760-5, pp. 312-3, 318.

"I Tbid. 1766-9, p. 437.

IIU Ibid. 1770-2, p. 273.

119 Ibid. pp. 541-2.

11 Ibid. p. 274.

118 Brentano's Gilds (1870), p. 130; Hale's Letter to Whitbread (1816) pp. 13-9.

'I' Brentano, p. 127 ; Dowell's Taxation (1888), ii. 201.

is Corry's Macclesfield, p. 61.
} 
those paid to Macclesfield weavers to-day. ${ }^{121}$ Compared with France, where Lyons was the centre of much casual and miserably paid labour, the country paid its silk journeymen well, and there seem to have been few complaints outside Spitalfields that the employers absorbed an undue proportion of the profits of the trade. We may indeed regard England's policy towards the silk industry in the eighteenth century as mercantilism at its best. It is true that its protectionist system was immoderate and not absolutely scientific, that much may be said against its too frequent interference in the normal tides of work and wages. It is also true that it made the classes in society which indulged in the use of silk pay more for that luxury than was required by the natural processes of untrammelled production and exchange. Yet these disadvantages were not a price too high to pay for the growth of a great trade, which during the eighteenth century provided a large class of English people with regular and usefal employment.

Gerald B. Hertz.

12 Draper's Record, 25 July 1908. 